\title{
Morphological variation and aspects of the geographic distribution of Orobanche coerulescens Stephan ex Willd. (Orobanchaceae) on Ulleung-do and Dok-do Islands
}

\author{
Woong Lee ${ }^{1}$, Keum Seon Jeong ${ }^{2}$, Kyung Choi ${ }^{2}$, Jin Seok Kim ${ }^{3}$, \\ Seong Ho Cho ${ }^{4}$ and Jae-Hong Pak ${ }^{1 *}$ \\ ${ }^{I}$ Research Institute for Dok-do and Ulleung-do Island, Kyungpook National University, Daegu 41566, Korea \\ ${ }^{2}$ Division of Forest Biodiversity and Herbarium, Korea National Arboretum, Pochen 11186, Korea \\ ${ }^{3}$ Division of Plant Resources, National Institute of Biological Resources, Incheon 22689, Korea \\ ${ }^{4}$ Natural History Museum, Kyungpook National University, Gunwi 39033, Korea \\ (Received 30 November 2016; Revised 6 December 2016; Accepted 12 December 2016)

\section{이웅 ${ }^{1} \cdot$ 정금선 ${ }^{2} \cdot$ 최경 $^{2} \cdot$ 김진석 $^{3} \cdot$ 조성호 ${ }^{4} \cdot$ 박재홍 $^{1 *}$ \\ 1경북대학교 울릉도독도연구소, ${ }^{2}$ 국립수목원, ${ }^{3}$ 국립생물자원관, ${ }^{4}$ 경북대학교 자연사박물관} \\ 울릉도, 독도 초종용에서 형태 변이와 지리적 분포 양상
}

\begin{abstract}
We investigate the intraspecific morphological variations and geographical distributions from twelve populations (28 samples) of Orobanche coerulescens in Korea. Two main morphological types were detected, i.e., glabrous (G-type) and pilose (P-type), in the external morphology (stem, leaf, bract, calyx, and corolla). The G-type was found on Ulleung-do and Dok-do, and the P-type was observed on the coasts of South Korea, Jeju-do and Ulleung-do. The distinct difference in the morphological types and geographical distribution suggested the existence of two putative lineages with different distribution processes. $O$. coerulescens, distributed in very limited areas, was only identified as the G-type on Dok-do. Hence, conservation efforts should focus on protecting native habitats to conserve native species and the unique biogeographic significance of this species.
\end{abstract}

Keywords: Orobanche coerulescens, morphological variation, geographic distribution, Ulleung-do, Dok-do, conservation

적 요: 한국내의 초종용은 한반도의 서해, 남해, 동해의 해안가 및 도서지역에 제한적으로 분포한다. 본 연 구는 울릉도와 독도를 중심으로 12 개 자생지에서 초종용의 종내 형태형질 변이를 관찰하고 지리적 분포 양 상을 조사하였다. 그 결과, 외부 형질(줄기, 잎, 포엽, 꽃받침 그리고 화관)에서 털의 유무에 의하여 두 개의 type (G-type, glabrous; P-type, pilose)을 확인하였다. 확인된 두 개의 형태학적 type은 확인된 자생지에서 뚜 렷한 지리적 분포 양상을 보여주었다. 한반도와 제주도에는 P-type, 울릉도에는 G-type과 P-type 그리고 독도 의 동도에는 G-type만이 관찰되었다. 초종용은 외부 형태 형질에 의하여 서로 다른 두 개의 type이 확인되고 뚜렷한 지리적 분포 양상을 보여주기 때문에, 털이 없어지는 형태적 변이가 단순히 일시적인 우연의 결과물 이 아니라 초종용 내에 이주 및 군체 형성의 과정을 동반하는 진화적으로 서로 다른 계통이 있음을 추정할 수 있다. 제한된 지역에서 분포하는 독도의 초종용은 유일하게 G-type 으로 확인되었으며 이는 독도 자생종 의 의미와 함께 중요한 식물지리학적 가치를 가지고 있기 때문에 자생지 보전을 위한 노력이 필요하다.

주요어: 초종용, 갯제비쑥, 형태학적 변이, 지리적 분포, 울릉도, 독도

\footnotetext{
*Author for correspondence: jhpak@knu.ac.kr
} 
초종용(Orobanche coerulescens Stephan ex Willd.)은 열당 과(Orobanchaceae) 초종용속(Orobanche L.)에 속하고, 초종 용속은 열당과에서 170 여 종의 기생식물(parasitic plant)을 포함하는 속으로 주로 북반구에 분포한다(Young et al., 1999). 한반도에 분포하는 초종용속에는 $O$. coerulescens Stephan ex Willd. (초종용), O. filicicola Nakai (백양더부살이), $O$. pycnostachya var. amurensis Beck. G. (압록더부살이), $O$. pycnostachya Hance (황종용), O. coerulescens for. nipponica (Makino) Kitam.(민초종용) 등이 보고되어 있으며, 흰 꽃이 피는 초종용도 알려져 있다(An and Hong, 2003; Hyun et al., 2003; Hong, 2007; Sun et al., 2014). 초종용은 주로 중앙유럽 (오스트리아, 독일 등)에서부터 중앙아시아(카자흐스탄, 몽골 등)를 거쳐 한국, 러시아, 중국, 일본, 대만 등지에 넓 게 분포한다(Hsiao, 1978; Zhang and Tzvelev, 1998; Novopokrovskii, 2000; Al-Shehbaz et al., 2006; Hong, 2007; Piwowarczyk and Przemyski, 2009; Piwowarczyk, 2012).

한국 내의 초종용은 주로 한반도의 서해, 남해, 동해의 해안가 및 도서지역에 제한적으로 분포하고 서식지내의 집단 크기 및 개체수가 작을 뿐만 아니라 인위적 훼손에 의하여 지속적으로 개체수가 감소하는 위험에 처해 있다. 특히 울릉도와 독도는 대표적인 초종용 자생 지역이지만 도로 및 건물 등의 지속적인 개발과 그에 따른 인위적 훼 손에 노출되어 있으며 생육지 내 토양 유실과 암석 붕괴 등 자연재해에 의하여 일순간 광범위한 훼손 위험성이 높 은 열악한 환경이다.
울릉도, 독도에 분포하는 초종용은 한반도와는 다르게 사철쏙(Artemisia capillaris Thunb.)이 아닌 갯제비쑥(A. japonica ssp. littoricola Kitam.)의 뿌리에 기생하는 특징과 함께 일반적으로 초종용의 표면이 부드러운 털로 덮여있 는 형태적 특징을 보이는 것과 달리 식물 전체에 털이 없고 매끈한 특징을 가지는 개체가 함께 확인되었다. Sun et al. (2014)은 울릉도에서 이와 같이 줄기, 잎 그리고 꽃의 표면 에 털이 없는(glabrous) 초종용의 형태학적 변이를 일본에 서 발표된 O. coerulescens for. nipponica (Makino) Kitam. (Kitamura and Murata, 1957)와 동일종으로 인식하고 국명을 민초종용으로 제시하였다. 특히 독도의 동도에서 확인되 는 모든 초종용은 식물 전체에 털이 없는 독특한 형태를 가 지고 있지만 지금까지 형태적 차이를 분명하게 인식하지 못하고 지속적인 훼손의 위험성에 노출되어 있기 때문에 이에 대한 연구 및 보전 계획 수립이 시급하다고 생각된다.

울릉도와 독도는 대륙과 한 번도 연결된 적이 없는 대양 섬으로 각각 200만 년과 400만 년 전 신생대 제 3기에 해저 화산활동에 의해 기원된 것으로 추정된다(Kim, 1985). 울릉 도, 독도와 같은 대양섬은 섬 고유식물의 독특한 생물학적 진화양상과 종분화 과정을 연구하기에 최적의 장소로 평 가되어 식물상, 식생, 분자생물학, 집단유전학 및 식물지리 학 등 다양한 접근이 시도되고 있다. 특히 울릉도와 독도의 경우는 섬 내에 생육하는 고유 관속식물 대부분이 대륙 선 구종의 원거리 분산에 의하여 정착한 후 분기진화보다는 절대적인 비율을 차지하는 향상진화의 경향을 보여주기

Table 1. Numbering and localities of 12 populations of Orobanche coerulescens in Korea and 28 samples of specimen (exsiccata and immersion) in the comparison of morphology.

\begin{tabular}{ccc}
\hline Population No. & Locality & Morphology type (voucher No. KNU) \\
\hline U01 & Is. Ulleung, Naesujeon & Glabrous (140518-1) \\
U02 & Pilose (120604-1, 140518-2) \\
U03 & Is. Ulleung, Sadong & Pilose (120604-2, 130717-1) \\
U04 & Is. Ulleung, Namseori & Pilose (130717-2) \\
& Is. Ulleung, Taeha & Glabrous (120604-3) \\
U05 & Is. Ulleung, Cheonbu & Pilose (120604-4, 130717-3) \\
U06 & Is. Ulleung, Seokpo & Pilose (150707-1) \\
& & Glabrous (140518-3, 150707-2) \\
U07 & Pilose (140518-4, 150707-3) \\
& Illeung, Seommok & Glabrous (120610-1, 130717-6) \\
D08 & Pilose (120610-2, 130717-7) \\
I09 & Is. Dok-do, Dong-do & Glabrous (130614-1, 140824-1) \\
H10 & Incheon, Eurwangni & Pilose (130605-1, 140604-1) \\
J11 & Haenam, Songpyeong & Pilose (130530-1, 140605-1) \\
P12 & Is. Jeju, Sinyang & Pilose (130705-1, 140609-1)
\end{tabular}

Glabrous and pilose means external morphology type (stem, leaf, bract, calyx, and corolla). 
A. Dok-do, Dong-do (G-type)

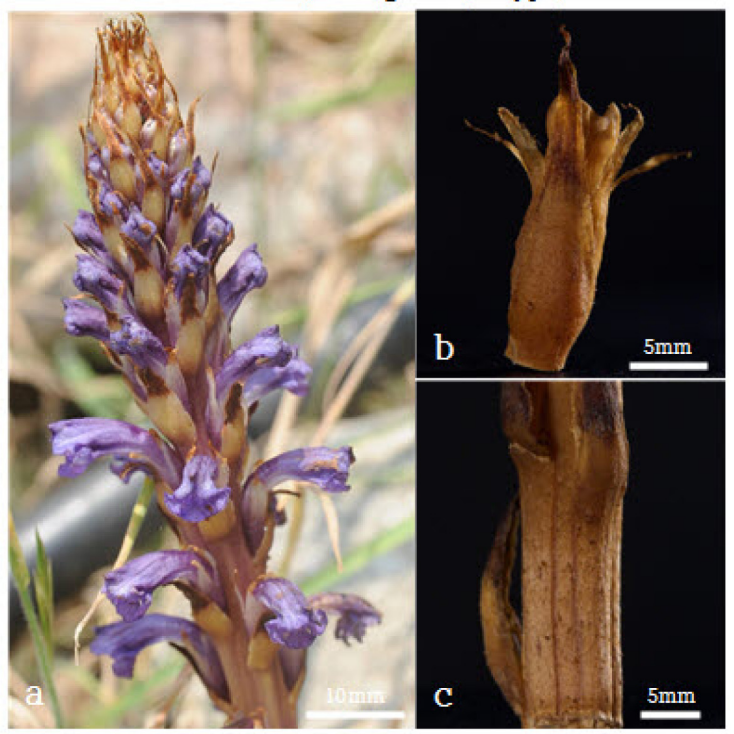

B. Ulleung-do, Naesujeon (P-type)

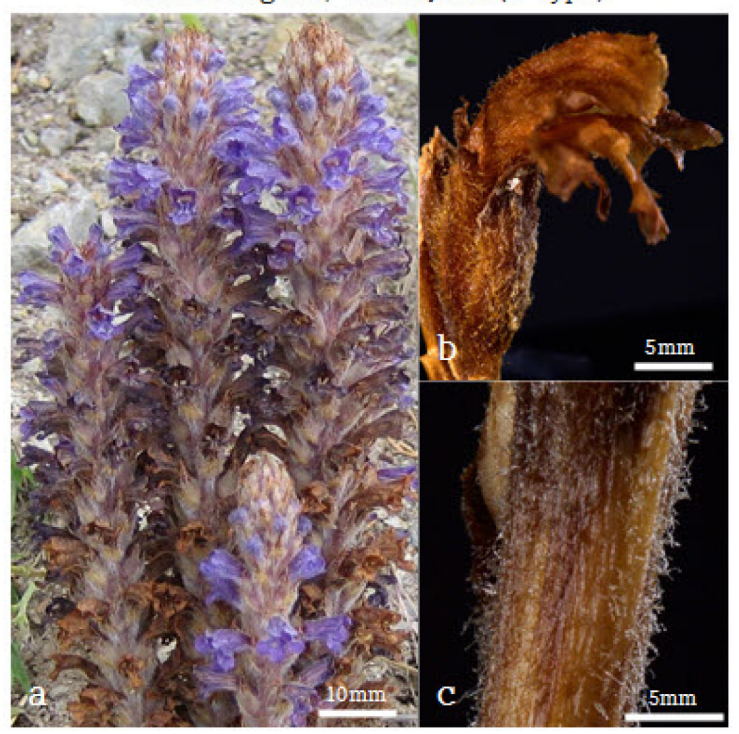

G-type

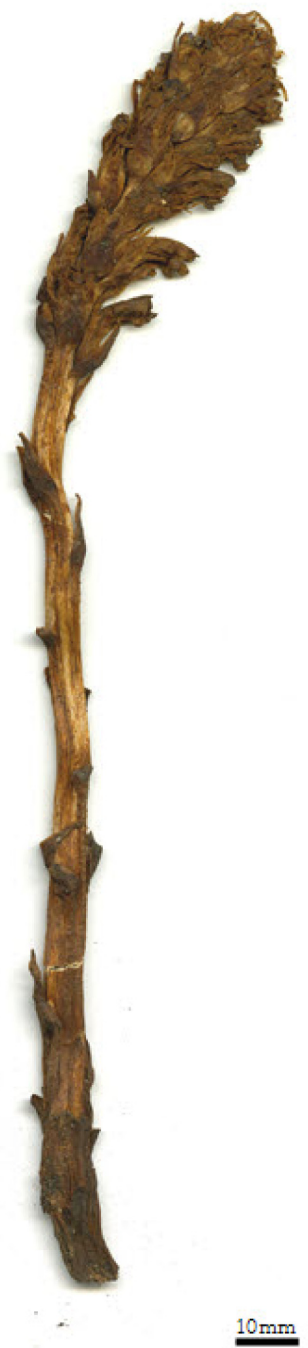

P-type

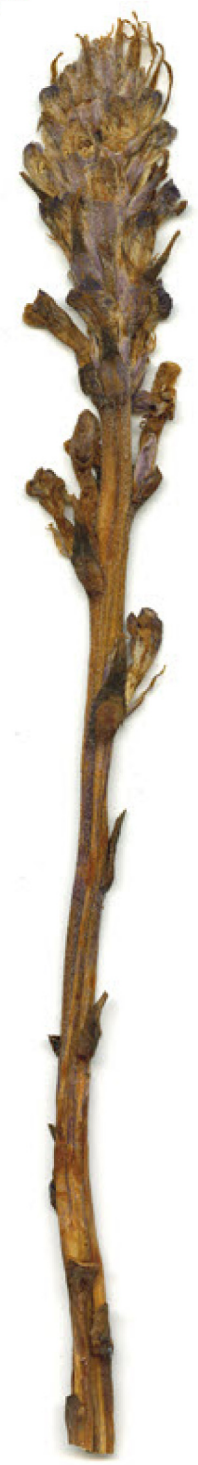

Fig. 1. Photographs of G-type (glabrous) and P-type (pilose) of Orobanche coerulescens in A (Dok-do, Dong-do) and B (Ulleung-do, Naesujeon). a. Habit; b. Flower (bract, calyx, corolla); c. Stem (leaf).

때문에 중요성이 부각되고 있다(Sun and Stuessy, 1998; Stuessy et al., 2006). 뿐만 아니라 지속적인 연구를 통해 신종 및 미기록종이 꾸준하게 발견되고 형태, 세포 그리고 분자 적 다양성이 관찰되어 그 가치가 더욱 크다(Pfosser et al., 2002, 2005; Lee and Pak, 2010; Jeong et al., 2014).

본 연구는 울릉도와 독도를 중심으로 한국에 분포하는 초종용의 형태학적 종내 변이를 처음으로 인식하고 그 지 리적 분포 특성을 파악하고자 하였다. 이는 향후 초종용 과 숙주식물(사철쑥, 갯제비쑥 등)의 세포·분자·지리학적 연구 및 대양섬인 울릉도·독도 희귀식물의 보전계획 수립 을 위한 기초자료로 제시하고자 한다.

\section{재료 및 방법}

재료

초종용의 외부 형태형질 변이 관찰 및 분포양상을 파 악하기 위하여 주요 자생지인 울릉도 7 개소, 독도 1 개소 와 한반도 및 제주도의 4 개소 등 총 12 개소에 대하여 2012년부터 2015년까지 반복적인 현지 조사를 수행하였 다(Table 1). 채집된 개체는 경북대학교 표본관(KNU)에 보관하였다. 그리고 본 연구의 결과로 확인된 형태학적 변이의 실체를 파악하기 위하여 국?내외의 문헌 조사를 수행하였다. 


\section{외부형태학적 연구}

외부 형태형질 관찰을 위하여 28개체에 대하여 건조표 본 및 액침표본( $70 \%$ 알코올)을 제작하였으며 육안 및 디 지털카메라(Body: Canon 60D, Japan; Lens: Canon $100 \mathrm{~mm}$ $\mathrm{f} / 2.8 \mathrm{AF}$ )를 이용하여 형태형질을 기록하고 관찰하였다.

\section{결과 및 고찰}

\section{형태형질 변이}

본 연구에서 울릉도 7 집단, 독도 1 집단의 초종용 자생 지를 중심으로 한반도 3 집단(동해, 서해, 남해)과 제주도 1 집단에 분포하는 28 개체에 대한 외부 형태형질 변이를 관찰하였으며, 줄기, 잎, 포엽, 꽃받침 그리고 화관에서 털 의 유무에 의하여 두 개의 type (glabrous 와 pilose, 이후에 G-type과 P-type으로 표시)으로 구분되었다(Table 1). 울릉 도와 독도에 분포하는 초종용은 모상표피(indumentum)의 유무, 분포양상(distribution), 줄기(stem), 인편(scales), 수상 꽃차례(spike), 포엽(bract), 꽃받침(calyx) 등의 외부형태 형 질에서 차이를 보였다. 울릉도와 독도의 초종용에서 확인 된 G-type은 식물 전체에 부드럽고 짧은 털이 완전히 없다 (glabrous)는 특징과 줄기와 인편의 돌기(protuberance), 포 엽과 꽃받침의 가장자리에 달리는 섬모(ciliate) 등의 차이 로 P-type과 구분되었다. 울릉도, 제주도 및 한반도에서 확 인된 P-type은 식물 전체가 부드럽고 짧은 털로 빽빽하게 덮여있는 특징을 보였다(Fig. 1, Table 2).

본 연구에서 확인된 형태학적 변이의 실체를 파악하기 위하여 국.내외 문헌 조사를 수행하였으며 러시아와 일본
에서 G-type과 유사한 형태학적 특징을 가지는 두 종을 확 인하였으나 표본은 관찰하지 못하였으며 기재문과 문헌을 통하여 형태를 비교하였다. O. glaucantha Trautv. (Trautvetter, 1871)는 동러시아의 Baikal 호수에 인접한 Irkutsk 지역에 서 분포하고 식물 전체에 털이 없는 특징, 많은 수의 인편, 인편의 모양이 피침형(lanceolate), 포엽이 피침형, 꽃받침 이 피침형이고 가장자리에 이빨형의 거치가 있으며 꽃이 짙은 파랑색(bluish)이며 건조 시에도 색이 유지되는 특징 을 기록하고 있다. O. nipponica Makino (Makino, 1928)는 일 본의 Honshu와 Kyushu 지역에 분포하고 O. glaucantha와 비교하여 식물 전체에 털이 없는 특징은 동일하지만 꽃이 보라색(violet-purple)이고 인편의 돌기, 엉성하게 달리는 인편, 포엽과 꽃받침의 가장자리에 섬모(ciliate)가 있다고 기록되어 차이가 있다. 이상의 결과를 통하여 독도 및 울 릉도에서 관찰된 G-type은 일본에서 보고된 O. nipponica와 식물 전체에 털이 없고 꽃은 보라색이며 인편에 돌기, 포 엽과 꽃받침에서 섬모가 관찰되는 특징을 공유하였다. 그 러나 독도와 울릉도에서 관찰되는 G-type은 갯제비쑥이 기주식물이고 O. nipponica는 제비쑥을 기주식물로 삼는 차이점도 확인하였다(Table 2). 따라서 G-type이 일본의 $O$. nipponica와 동일한 종인지 아니면 울릉도와 독도 초종용 에서 발생된 변이인지에 대해서는 직접적인 비교 연구 및 분자학적 접근 등 다양한 추가 연구가 필요하다. 또한 이 러한 형태학적 차이를 초종용과 이 두 종을 다른 종으로 분류할 수 있는 유용한 형질인가에 대해서는 초종용의 형 태적 다양성에 근거하여 논란의 여지가 충분하다.

초종용이 속하는 열당과 초종용속은 전기생(holoparasitic)

Table 2. Morphological feature of Orobanche coerulescens (P-type and G-type), O. nipponica and O. glaucantha from specimen and description literatures.

\begin{tabular}{|c|c|c|c|c|}
\hline Character & $\begin{array}{c}\text { O. coerulescens } \\
\text { (P-type in Ulleung-do) }\end{array}$ & $\begin{array}{c}\text { O. coerulescens } \\
\text { (G-type in Dok-do) }\end{array}$ & O. nipponica & O. glaucantha \\
\hline $\begin{array}{l}\text { Plant } \\
\text { indumentum }\end{array}$ & Densely pilose & Glabrous & Glabrous & Glabrous \\
\hline Host plants & $\begin{array}{c}\text { Artemisia japonica ssp. } \\
\text { littoricola }\end{array}$ & A. japonica ssp. littoricola & A. japonica & Artemisia sp. \\
\hline $\begin{array}{l}\text { General } \\
\text { distribution }\end{array}$ & $\begin{array}{l}\text { Korea, Japan, China, Russia, } \\
\text { Taiwan, Europe, Mongolia, } \\
\text { etc. }\end{array}$ & $\begin{array}{c}\text { Korea } \\
\text { (Ulleung-do and Dok-do) }\end{array}$ & $\begin{array}{c}\text { Japan } \\
\text { (Honshu, Kyushu) }\end{array}$ & $\begin{array}{c}\text { Russia } \\
\text { (Eastern Siberia, Irkutsk) }\end{array}$ \\
\hline Stem & Scattered scaly & Scattered scaly protuberance & Sub-flexuous, scattered scaly & Numerous scaly \\
\hline Scales & Ovate-subulate & Ovate-subulate protuberance & Ovate-subulate, adpressed & Lanceolate, numerous \\
\hline Spike & $\begin{array}{l}\text { Rather densely arranged } \\
\text { flowers }\end{array}$ & $\begin{array}{l}\text { Rather loosely } \\
\text { arranged flowers }\end{array}$ & $\begin{array}{l}\text { Rather loosely } \\
\text { arranged flowers }\end{array}$ & $\begin{array}{l}\text { Rather densely } \\
\text { arranged flowers }\end{array}$ \\
\hline Bract & $\begin{array}{l}\text { Ovate, acuminate, } \\
15-20 \mathrm{~mm}\end{array}$ & $\begin{array}{l}\text { Ovate, acuminate, ciliate, } \\
\qquad 15 \mathrm{~mm}\end{array}$ & $\begin{array}{l}\text { Ovate, acuminate, ciliate, } \\
8-15 \mathrm{~mm}\end{array}$ & $\begin{array}{l}\text { Lanceolate, long acuminate, } \\
\text { approx. as long as the flower }\end{array}$ \\
\hline Calyx & $\begin{array}{l}\text { Narrowly ovate, } \\
\text { to } 1 / 3 \text { equal bifid }\end{array}$ & $\begin{array}{l}\text { Narrowly ovate, ciliate, } \\
\text { to } 1 / 3 \text { equal bifid }\end{array}$ & Narrowly ovate, ciliate & $\begin{array}{l}\text { Lanceolate, } \\
\text { teeth linear-subulate }\end{array}$ \\
\hline Corolla & Violet-purple & Violet-purple & $\begin{array}{l}\text { ca. } 20-22 \mathrm{~mm}, \\
\text { violet-purple }\end{array}$ & $\begin{array}{l}\text { ca. } 15-20 \text {, intense bluish } \\
\text { (also in dry state) }\end{array}$ \\
\hline
\end{tabular}




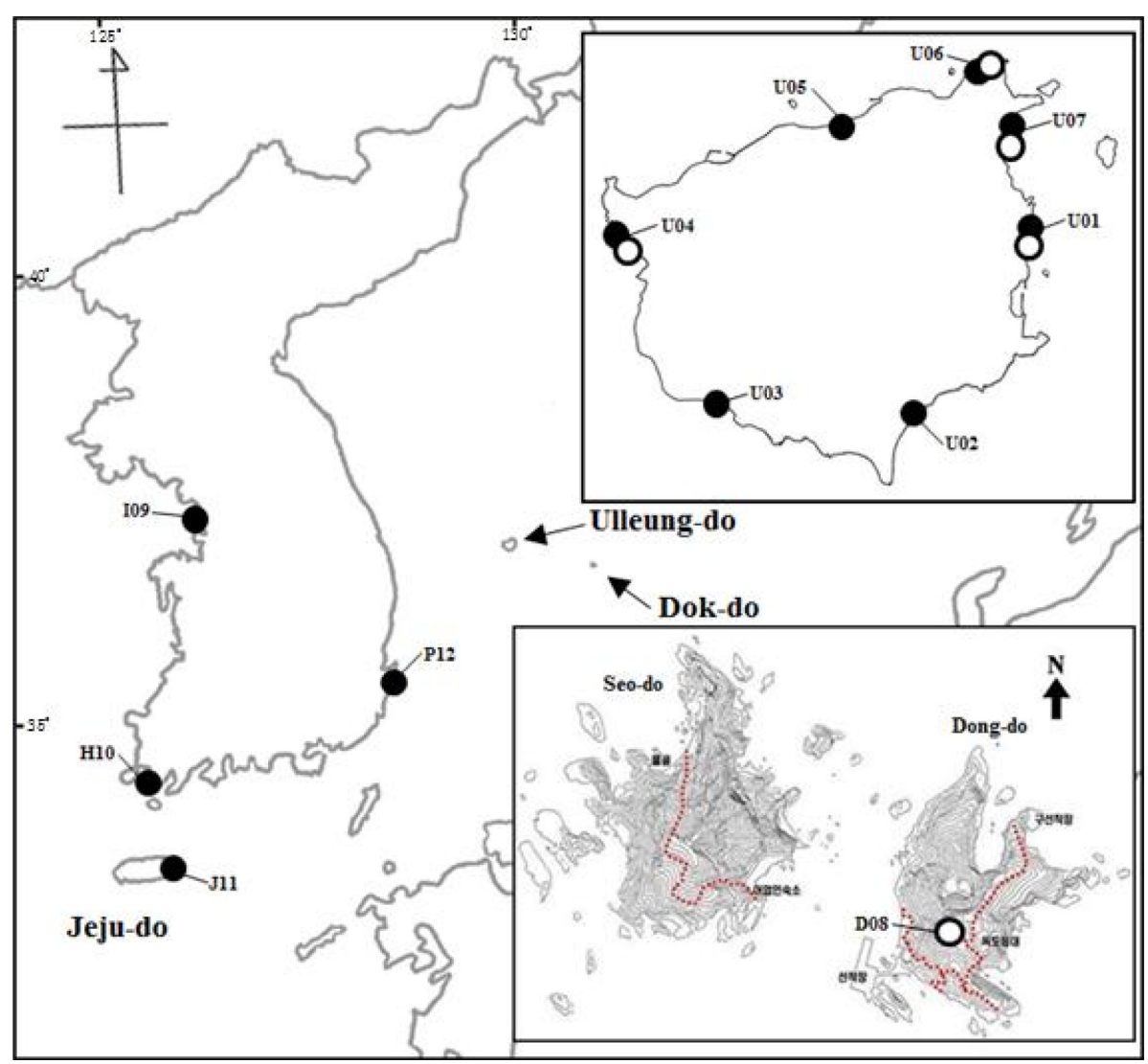

Fig. 2. Distribution of two morphology types of Orobanche coerulescens: G-type (०) and P-type (•).

의 생활형에서 비롯되는 숙주식물의 다양성과 그에 따른 다양한 생태형의 존재, 종의 식별에 유용한 형태형질의 부족과 다양한 형태형질 변이(잎의 형태 변이와 함께 수 의 급격한 변화, 꽃의 수, 크기, 모양, 색깔 등에서 변이, 고 유의 특징이 없는 열매 및 종자 형태 등) 그리고 건조 표본 이 고유의 색을 잃고 검어지는 현상 등으로 인해 형태학 적 형질의 관찰을 통한 분류체계 수립에 어려움이 있다 (Young et al., 1999; Gerald, 2004; Manen et al., 2004, Gevezova et al. 2012). 결과적으로 현재는 다양한 지역적 변이를 초종용으로 통합하는 경우가 많으며 이에 대한 관 련 연구는 아직까지 미흡하다(Hsiao, 1978; Zhang and Tzvelev, 1998; Novopokrovskii, 2000; Al-Shehbaz et al., 2006; Hong, 2007). 최근에는 초종용속에서 종 분류에 유용한 형 태형질의 부족과 형태적 다양성에 의하여 뚜렷한 분류 체 계 수립이 어렵기 때문에, 분자생물학적 분석방법을 통하 여 종 분류뿐만 아니라 계통발생연구, 계통생물지리학 및 종분화 양상 연구 등을 수행하고 있다(Wolfe and dePamphilis, 1997; Young et al., 1999; Manen et al., 2004; Schneeweiss et al., 2004; Park et al., 2008).

\section{지리적 분포 양상}

본 연구에서 초종용의 종내 형태학적 변이와 지리적 분
포 양상의 연관성은 종의 실체에 대해 논의 할 수 있는 의 미 있는 정보를 제공한다. 일반적으로 식물 전체에 털이 있 는 형태(P-type)의 초종용은 중앙유럽에서부터 중앙아시 아를 거쳐 한국, 러시아, 중국, 일본, 대만 등지에 넓게 분포 한다(Hsiao, 1978; Zhang and Tzvelev, 1998; Novopokrovskii, 2000; Al-Shehbaz et al., 2006; Hong, 2007; Piwowarczyk and Przemyski, 2009; Piwowarczyk, 2012). 그러나 식물 전체에 털이 없는 형태(G-type)는 한국의 울릉도와 독도에서 관찰 하였다. 우리는 초종용 자생지의 현지 조사와 모니터링을 통하여 한국 내에서 한반도와 제주도에는 P-type, 울릉도 에는 G-type과 P-type 그리고 독도의 동도에는 G-type만이 관찰되는 뚜렷한 지리적 분포 특이성을 본 연구에서 확인 하였다(Fig. 2). 그리고 초종용 G-type과 유사성을 보이는 일본의 O. nipponica는 Honshu와 Kyushu 지역에 분포하고 러시아의 O. glaucantha는 Eastern Siberia, Irkutsk 지역에 분 포하여 동러시아, 일본, 울릉도와 독도를 포함하는 분포 특이성을 보여준다(Table 2). 또한 울릉도와 독도에 분포 하는 초종용의 숙주식물인 갯제비쑥은 초종용 G-type 과 일치하는 독특한 분포 양상을 보여줌으로서 과거 지사학 적 유사성이 있음을 추정할 수 있다. Park과 Chung (2012) 은 한반도의 동해안에 갯제비쑥이 분포하지 않고 울릉도 와 독도에 제비쑥이 분포하지 않는 특이성 및 화분학적 

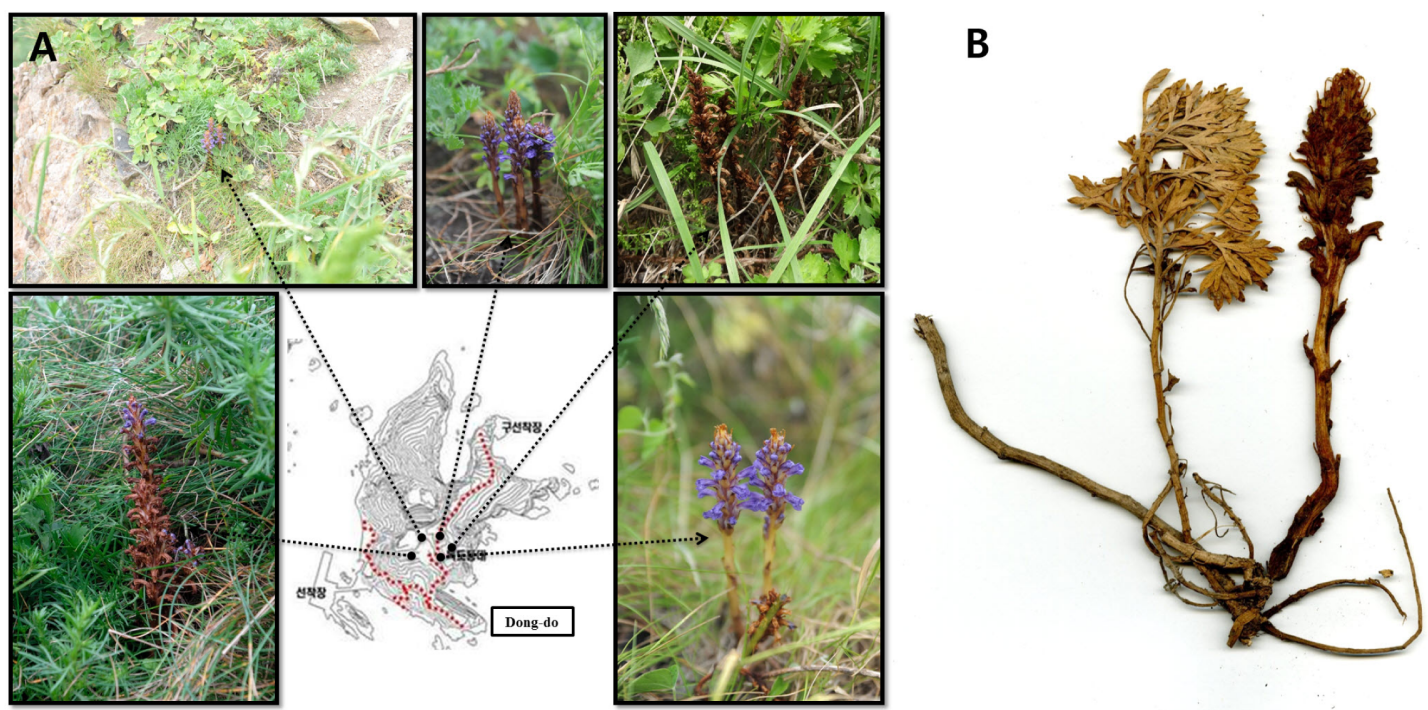

Fig. 3. Distribution and specimen of Orobanche coerulescens (G-type) on Dok-do. A. habitats. B. on the roots of Artemisia japonica ssp. littoricola.

연구를 종합하여, 갯제비쑥은 종분화 이후 사할린, 쿠릴 열도, 일본열도에서부터 울릉도와 독도로 이동한 후에 섬 이라는 제약된 환경에서 고립되어 정착하였다고 판단하 였다.

따라서 형태학적 차이 및 지리적 분포 특이성을 종합하 면 식물체 전체에서 털이 없어지는 형태적 변이가 단순히 일시적인 우연의 결과물이 아니라 초종용 내에 이주 및 군체 형성의 과정을 동반하는 진화적으로 서로 다른 계통 이 있음을 추정할 수 있다.

\section{자생지의 훼손과 보전의 필요성}

초종용은 식물구계학적 특정식물종 $\mathrm{V}$ 등급 및 희귀식 물로 그 분포가 제한적이고 대부분의 자생지가 해안 가까 이에 형성되어 자연적, 인위적 훼손이 심각하다. 2012년 부터 모니터링을 통하여 확인한 결과, 인천 을왕리 집단 은 기주식물인 사철쑥의 자생지 면적이 감소하고 이와 함 께 식물체를 뿌리째 파헤친 인위적 채집 흔적이 관찰되었 다. 해남 송평해변, 제주 신양해변의 집단 또한 해수옥장 및 도로에 접해 있기에 모래 유실과 사철쑥의 자생지 면 적 감소 등 인위적 훼손에 노출되어 개체수가 감소하고 있다. 특히 포항 구룡포 집단은 2016년에 시작된 해안가 건축으로 인하여 자생지가 심각하게 훼손되었다. 또한 한 국에서 가장 큰 초종용 자생지로 판단되는 울릉도는 일주 도로 건설과 해안가 건축, 태풍 또는 자연 붕괴 등에 의하 여 대규모의 자생지가 점점 사라져 가고 있는 실정이다.

본 연구에서 확인한 초종용 G-type 개체들은 울릉도와 독도의 제한된 지역에 분포하고 울릉도에서는 집단별로 5(내수전)-25(석포)여 개체, 독도에서는 동도의 독도경비 대 막사 주변으로 총 20 여 개체만 확인될 정도로 집단의
크기가 작다. 울릉도 자생지는 석포와 섬목 일대에서 다 수의 개체가 확인되었으나 도로변을 따라 좁고 길게 형성 된 자생지는 훼손에 취약한 것으로 판단된다. 위협 요인 을 살펴보면 낙석 및 토사 붕괴와 건축에 의한 자생지내 절멸, 자동차 및 사람에 의한 지속적인 영향 등에 노출되 어 있다. 특히 동도의 초종용은 1952년부터 수행된 20여 차례의 식물 조사 동안 지속적으로 관찰된 분류군이지만 (Lee et al., 2007; Jung et al., 2014; Sun et al., 2014), 식물 전 체에 털이 없는 독특한 형태적 차이를 분명하게 인식하지 못하였다. 동도의 초종용 자생지를 살펴보면 독도경비대 막사 주변으로 5 집단을 확인할 수 있으며 이중에서 막사 서쪽 편 경사지에서 10-15개체가 분포한다. 자생지내 출 현종은 갯제비쑥, 해국(Aster sphathulifolius Maxim.), 괭이 밥(Oxalis corniculata $\mathrm{L}$.), 개밀[Agropyron tsukusinense var. transiens (Hack.) Ohwi], 술패랭이꽃(Dianthus superbus var. longicalycinus WILLIAMS), 큰이삭풀( Bromus unioloides Kunth), 갓[Brassica juncea (L.) Czern.], 왕김의털(Festuca $r u b r a \mathrm{~L}$.), 땅채송화(Sedum oryzifolium Makino) 등을 관찰하 였으며 독도에는 갯제비쑥(A. japonica ssp. littoricola)과 산 쑥(A. montana Pampan) 등 2종의 Artemisia 속 식물이 관찰 되며 이 중에서 갯제비쑥의 뿌리에 초종용(G-type)이 기생 함을 확인하였다(Fig. 3). 독도 초종용은 식물체 전체에서 털이 없는(globrous) 개체가 관찰되는 형태적 특이성뿐만 아니라 독도라는 지리적 특이성과 독도 식물상 조사의 초 기부터 관찰된 독도 자생종으로서의 가치도 높다고 판단 된다. 그러나 동도는 인간 활동에 의한 인위적 간섭, 나무 식재 사업 및 생물자원 채집에 의한 자생지 훼손 등의 위 험에 쉽게 노출되어 있다.

초종용과 가까운 유연관계를 가지는 백양더부살이 $(O$. 
filicicola)는 제한적인 분포와 훼손의 위험성 때문에 멸종 위기종 2급으로 지정하여 보호되고 있다. 울릉도와 독도 의 초종용은 형태적 특이성(P-type과 G-type)과 대양섬에 분포하는 지리적 특이성 그리고 훼손의 위험성 등을 고려 하여 향후 지속적인 연구와 보전 전략 수립이 필요하다고 판단된다. 따라서 자생지 보전을 위한 보호 구역 및 기간 설정, 반출승인 제한 생물 지정 등과 같은 보전 전략 수립 이 시급하다. 따라서 앞으로 울릉도와 독도에 자생하는 초종용을 중심으로 지속적인 개체군 변동 모니터링을 수 행하고 일본 및 러시아 등 주변 지역의 연관종에 대한 추 가 연구, 분자생물학적 방법을 통하여 계통생물지리학 및 종분화 양상을 파악하여 분류체계와 보전 전략 수립 등을 위한 기초 자료를 제시하여야 하겠다.

\section{사 사}

이 논문은 2016년도 정부(교육부)의 재원으로 한국연구 재단의 지원을 받아 수행된 기초연구사업임(No. 2016R1A 6A1A05011910).

\section{Literature Cited}

Al-Shehbaz, I. A., K. Aria and H. Ohba. 2006. Orobanchaceae. In Flora of Japan. Vol. 2a. Iwatsuki, K., D. E. Boufford and H. Ohba (eds.), Kodansha Ltd., Tokyo. Pp. 454-511.

An, B.-C. and S.-P. Hong. 2003. Systematic application of seed morphology in Korean Orobanchaceae. Korean Journal of Plant Taxonomy 33: 411-420.

Gerald, M. S., T. Palomeque, A. E. Colwell and H. Weiss-Schneeweiss. 2004. Chromosome numbers and karyotype evolution in holoparasitic Orobanche (Orobanchaceae) and related genera. American Journal of Botany 91(3): 439-448.

Gevezova, M., T. Dekalska, K. Stoyanov, T. Hristeva, K. Kostov, R. Batchvarova and I. Denev. 2012. Recent advances in Broomrapes research. Journal of Bioscience and Biotechnology 1: 91-105.

Hsiao, J.-Y. 1978. Orobnachaceae. In Flora of Taiwan, Vol. 4. Editorial Committee of the Flora of Taiwan (ed.), Epoch Publishing Company, Ltd., Taipei. Pp. 688-692.

Hong, S.-P. 2007. Orobanchaceae. In The Genera of Vascular Plants of Korea. Park, C.-W. (ed.), Academy Publishing Co., Seoul. Pp. 892-895.

Hyun, J.-O., Y. Lim and H. Shin. 2003. Validation of Orobanche filicicola (Orobanchaceae) from Korea. Novon 13: 64-67.

Jeong, K. S., M. S. Kim, W. Lee and J.-H. Pak. 2014. Intraspecific variation and geographic study of Lonicera insularis (Caprifoliaceae) based on chloroplast DNA sequences. Korean Journal of Plant Taxonomy 44: 202-207.
Jung, S.-Y., J.-G. Byun, S.-H. Park, S.-H. Oh, J.-C. Yang, J.-W. Jang, K.-S. Chang and Y.-M. Lee. 2014. The study of distribution characteristics of vascular and naturalized plants in Dokdo, South Korea. Journal of Asia-Pacific Biodiversity 7: e197-e205.

Kim, Y. K. 1985. Petrology of Ulleung volcanic island, Korea. Part 1. Geology. Journal of Japanese Association of Mineralogists, Petrologists and Economic Geologists 80: 128-135.

Kitamura S. and G. Murata. 1957. New names and new conceptions adopted in our coloured illustrations of herbaceous plants of Japan (Sympetalae). Acta Phytotaxonomica et Geobotanica 17: 5-13.

Lee, D. H., S. H. Cho and J. H. Pak. 2007. The analysis of vascular plant species composition in Dok-do island. Korean Journal of Plant Taxonomy 37: 545-563.

Lee, W. and J.-H. Pak. 2010. Intraspecific sequence variation of tr $\mathrm{L} / \mathrm{F}$ intergenic region (cpDNA) in Sedum takesimense Nakai (Crassulaceae) and aspects of geographic distribution. Korean Journal of Plant Taxonomy 40: 157-162.

Makino, T. 1928. A contribution to the knowledge of the flora of Japan. The Journal of Japanese Botany 5: 40-41.

Manen, J.-F., C. Habashi, D. Jeanmonod, J.-M. Park and G. M. Schneeweiss. 2004. Phylogeny and intraspecific variability of holoparasitic Orobanche (Orobanchaceae) inferred from plastid $r b c \mathrm{~L}$ sequences. Molecular Phylogenetics and Evolution 33: $482-500$.

Novopokrovskii, I. V. 2000. Orobanchaceae. In Flora of the U.S.S.R. Vol. 23. Komarov V. L. (eds.), Shiva Offset Press, Indore. Pp. 21-145.

Park, J.-M., J.-F. Manen, A. E. Colwell and G. M. Schneeweiss. 2008. A plastid gene phylogeny of the non-photosynthetic parasitic Orobanche (Orobanchaceae) and related genera. Journal of Plant Research 121: 365-376.

Park, M. S. and G. Y. Chung. 2012. A palynological study of the genus Artemisia L. (Asteraceae) in Korea. Korean Journal of Plant Taxonomy 42: 24-39.

Pfosser, M., G. Jakubowsky, P. M. Schlüter, T. Fer, H. Kato, T. F. Stuessy and B.-Y. Sun. 2005. Evolution of Dystaenia takesimana (Apiaceae), endemic to Ullung island, Korea. Plant Systematics and Evolution 256: 159-170.

Pfosser, M. F., J. Guzy-Wróbelska, B.-Y. Sun, T. F. Stuessy, T. Sugawara and N. Fujii. 2002. The origin of species of Acer (Sapindaceae) endemic to Ullung Island, Korea. Systematic Botany 27: 351-367.

Piwowarczyk, R. 2012. The genus Orobanche L. (Orobanchaceae) in the Malopolska Upland (S Poland): distribution, habitat, host preferences, and taxonomic problems. Biodiversity Research and Conservation 26: 3-22. 
Piwowarczyk, R. and A. Przemyski. 2009. New locality of Orobanche coerulescens Stephan ex Willd. (Orobanchaceae) at the NW limit of its geographical range. Acta Societatis Botanicorum Poloniae 78: 291-295.

Schneeweiss, G. M., A. Colwell, J.-M. Park, C.-G. Jang and T. F. Stuessy. 2004. Phylogeny of holoparasitic Orobanche (Orobanchaceae) inferred from nuclear ITS sequences. Molecular Phylogenetics and Evolution 30: 465-478.

Stuessy, T. F., G. Jakubowsky, R. S. Gómez, M. Pfosser, P. M. Schlüter, T. Fer, B.-Y. Sun and H. Kato. 2006. Anagenetic evolution in island plants. Journal of Biogeography 33: 12591265.

Sun, B.-Y., H. C. Shin, J.-O. Hyun, Y.-D. Kim and S.-H. Oh. 2014. Vascular plants of Dokdo and Ulleungdo islands in Korea. National Institute of Biological Resources, Incheon, 360 pp.

Sun, B.-Y. and T. F. Stuessy. 1998. Preliminary observations on the evolution of endemic angiosperms of Ulleung Island, Korea. In Evolution and Speciation of Island Plants, Stuessy, T. F. and
Ono, M. (eds.), Cambridge University Press, Cambridge. Pp. 181-202.

Trautvetter, E. R. V. 1871. Acta horti petropolitani. St. Petersburg. Trudy Imperatorskago S.-Peterburgskago Botaniceskago Sada 1: $26-27$.

Wolfe, A. D. and C. W. dePamphilis. 1997. Alternate paths of evolution for the photosynthetic gene $r b c \mathrm{~L}$ in four nonphotosynthetic species of Orobanche. Plant Molecular Biology 33: 965-977.

Young, N. D., K. E. Steiner and C. W. dePamphilis. 1999. The evolution of parasitism in Scrophulariaceae/Orobanchaceae: plastid gene sequence refute an evolutionary transition series. Annals of the Missouri Botanical Garden 86: 876-893.

Zhang, Z. and N. N. Tzvelev. 1998. Orobanchaceae. In Flora of China, Vol. 18. Wu, Z. Y. and P. H. Raven (eds.), Science Press, Beijing and Missouri Botanical Garden, St. Louis, MO. Pp. 229-243. 